DOI: https://doi.org/10.33989/2075-146x.2021.27.247069

УДК 378.091.322:001.895

\title{
НАТАЛІЯ КОНОНЕЦ
}

ORCID

\section{СВІТЛАНА НЕСТУЛЯ}

ORCID

ВНЗ Укоопспілки «Полтавський університет економіки і торгівлі»

\section{ІННОВАЦІЙНІ ФОРМИ СЕМІНАРСЬКИХ ЗАНЯТЬ У ПРОЦЕСІ ПРОФЕСІЙНОГО ЗРОСТАННЯ МАГІСТРАНТІВ ОСВІТНЬОЇ ПРОГРАМИ «ПЕДАГОГІКА ВИЩОЇ ШКОЛИ»}

\begin{abstract}
Проаналізовано суть інноваційних форм організації семінарських занять у процесі професійного зростання магістрантів освітньої програми «Педагогіка вищої школи» галузі знань 01 Освіта/Педагогіка спеціальності 011 Освітні, педагогічні науки. Схарактеризовано такі форми інноваційних семінарських занять, які сприятимуть професійному зростанню магістрантів під час навчання у закладі вищої освіти: семінар-розгорнута бесіда, семінардоповідь (повідомлення), обговорення рефератів і творчих робіт, коментоване читання, семінар-розв'язування задачі, семінар у формі телепередачі, семінар-диспут (дискусія), семінар-конференція, семінар-прес-конференція, проблемний семінар, семінар-аукціон, семінар-вікторина, семінар-змагання (турнір), вебінар.

Ключові слова: магістр, педагогіка вищої иколи, семінарське заняття, семінар професіоналізациї, інновації
\end{abstract}

Постановка проблеми. Освітня програма «Педагогіка вищої школи» 3 підготовки магістрів-майбутніх викладачів закладів вищої освіти (ЗВО) надає фахову освіту та спрямовується на підготовку сучасного педагогафахівця, що має міцні знання, уміє використовувати їх у практичній діяльності, патріота, гідного громадянина своєї держави. Магістранти здобувають професію викладача ЗВО, тому їх, у першу чергу, цікавлять навчальні дисципліни, які допомагають професійно зростати та удосконалюватися.

Аналіз нормативної документації освітньої програми свідчить, що вивчення фахових дисциплін (наприклад, «Педагогіка вищої школи», «Дидактичні системи у вищій школі», «Педагогічна майстерність викладача вищої школи», «Педагогічний контроль в системі освіти», «Планування і організація навчального процесу у вищій школі», «Проєктування професійної підготовки та діяльності фахівців», «Системний підхід у вищій школі», «Інноваційні технології у вищій школі» та ін.) передбачає таку форму організації навчання, як семінар. Проведення занять у формі семінару має сприяти професіоналізації магістрантів, їх самовизначенню як особистості, розуміння ними свого місця в педагогіці, своїх здатностей до професійно-педагогічної діяльності. Подібне заняття можна назвати семінаром професіоналізації, оскільки воно передбачає не лише засвоєння накопиченого професійно-педагогічного досвіду, певної системи знань про педагогіку і їі галузі, але й сприяє формуванню магістранта як особистості та фахівця (Малафіїк, 2015).

Аналіз останніх досліджень. Аналіз наукових праць (К. Бабенко, О. Брюховецька, М. Гриньова, О. Гурська, Ф. Лімбах, I. Малафіїк, I. Макєєва, С. Нестуля, І. Палагнюк, М. Палагнюк, М. Фіцула, А. Хуторський, Д. Чернілевський та ін.) дає підстави стверджувати, що у процесі опанування дисциплінами освітньої програми «Педагогіка вищої школи», семінарське заняття, безперечно, має бути семінаром професіоналізації. Відтак, у нашому дослідженні, семінар професіоналізації- це організаційно-змістова форма семінарського заняття із педагогічних дисциплін практико-орієнтованого характеру, яка передбачає комплексне засвоєння індивідом певної системи знань, норм і цінностей, що забезпечує трансформацію професійнопедагогічних ціннісних орієнтацій магістранта в його сталі переконання та оптимізує активовані під час відповідних лекцій процеси професійного становлення в парадигмі становлення та розвитку особистості викладача 3ВО сучасного інформаційного суспільства та формування відповідних загальних та спеціальних (фахових) компетентностей.

Мета статті - схарактеризувати суть інноваційних форм організації семінарських занять у процесі професійного зростання магістрантів освітньої програми «Педагогіка вищої школи» галузі знань 01 Освіта/Педагогіка спеціальності 011 Освітні, педагогічні науки.

Основний виклад матеріалу. Оскільки, як свідчить аналіз науково-педагогічної та методичної літератури, існують різні види семінарських занять (від навчальних, узагальнюючих до розгорнутої бесіди, дискусії, 
екскурсії, обговорення рефератів або доповідей тощо) (Гриньова, Кононец, Дяченко-Богун, Рибалко, 2019; Малафіїк, 2015; Фіцула, 2010; Чернилевский, 2020), потрібно обрати оптимальні інноваційні форми навчальної діяльності, які б поглинули увагу магістрантів, розкрили творчий потенціал та зацікавили до вивчення професійно-педагогічних значущих тем, а також слугували орієнтиром до використання у майбутній професійно-педагогічній діяльності. Такими інноваційними формами семінарських занять можуть бути (рис 1):

\begin{tabular}{|c|c|}
\hline $\begin{array}{l}\text { Семінарське } \\
\text { заняття у } 3 \mathrm{BO}\end{array}$ & 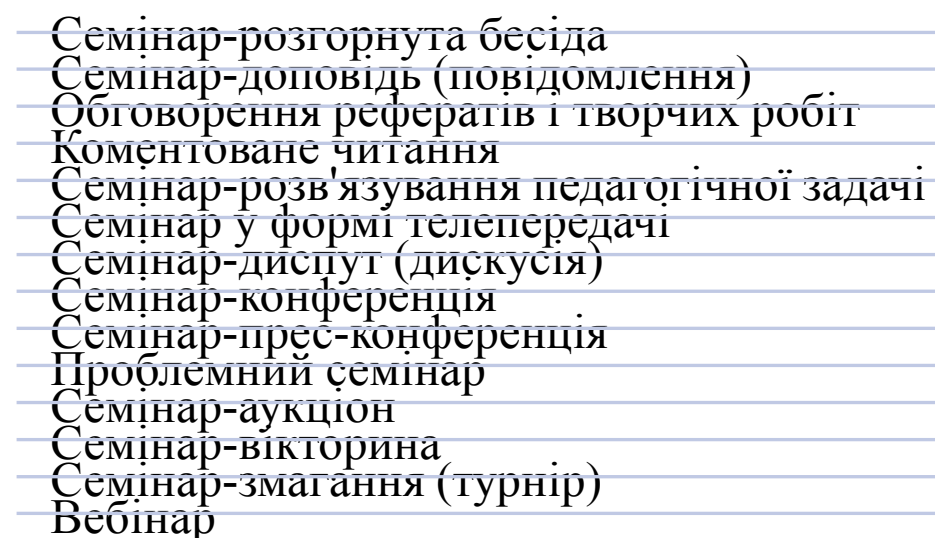 \\
\hline
\end{tabular}
$3 \mathrm{BO}$

Рис. 1. Інноваційні форми семінарських занять у процесі професійного зростання майбутніх викладачів

Семінар-розгорнута бесіда передбачає організацію навчальної діяльності магістрантів у формі бесіди. Така форма семінарського заняття дозволяє залучити максимум магістрантів до обговорення проблемного питання у межах опанування змістом дисципліни, іiі модуля чи окремо взятої теми. У іiі ході викладачем здійснюється заохочення, стимуляція магістрантів до висловлення власних позицій і думок, у магістрантів розвивається уміння дискутувати, виступати перед аудиторією, уточнювати та доповнювати доповідача.

Семінар-доповідь (повідомлення) відрізняється від попередньої форми тим, що, окрім грунтовної підготовки викладача до такої форми семінару, у ході його проведення один магістрант викладає свої думки, аргументуючи їх фактами та прикладами, а решта уважно слухають, щоб бути готовими доповнювати, підтверджувати чи спростовувати викладене.

Достатньо схожим на попередні форми є семінар-обговорення рефератів і творчих робіт. Його основне призначення - формування високого рівня самостійності і творчості магістрантів як важливих складників професійного зростання. Написання реферату чи певної творчої роботи має базуватися на принципах академічної доброчесності, а вміння захистити написану роботу - це розвиток умінь викласти та відстояти основні думки, дати відповіді на питання опонентів (інших магістрантів, викладача).

Коментоване читання, здебільшого, як самостійне семінарське заняття не практикується у ЗВО, а використовується, насамперед, у поєднанні з іншими формами роботи на семінарі. Так, на семінарі професіоналізації, наприклад, в межах вивчення дисципліни «Педагогіка вищої школи» коментоване читання можна використати для аналізу нормативного документу, закону, уривку з педагогічної літератури, наукової чи художньої тощо.

Семінар-розв'язування педагогічної задачі може бути доречним при вивченні будь-якої дисципліни освітньої програми «Педагогіка вищої школи». Його можна проводити як узагальнююче заняття 3 вивчення теми чи модуля. Іноді такі семінари можна зараховувати магістрантам як модульну контрольну роботу, під час якої чітко видно, чого навчитися, досягли магістранти. Так, в курсі «Педагогічна майстерність викладача вищої школи» вдалим прикладом є використання ситуаційних завдань, які дозволяють перевірити засвоєння системи знань 3 дисципліни, чи прослідкувати кросдисциплінарне застосування магістрантами набутих компетентностей.

Семінар у формі телепередачі. Власний досвід свідчить, що з цікавістю та ентузіазмом магістранти сприймають використання на семінарах елементів уроку-телепередачі (Малафіїк, 2015), що будується у стилі найпопулярніших телепрограм минулого і сьогодення: «Перший мільйон», «Ерудит», «Закон $є$ закон», «Найрозумніший». Використання таких ігрових моментів послаблює емоційне напруження магістрантів, активізує їх увагу та допомагає швидше адаптуватися до інноваційної специфіки змісту і форм презентації та сприйняття змісту професійно-педагогічних дисциплін. 3 іншого боку, вони мають можливість ознайомитися 3 методикою проведення такої інноваційної форми семінару і в майбутньому ії застосувати самостійно.

Семінар-диспут (дискусія), як свідчить практика, є доволі поширеною формою семінарського заняття, адже така форма захоплює магістрантів, стимулює інтерес до змісту дисципліни, мотивує, сприяє засвоєнню навчального матеріалу, водночас розвиваючи логічне мислення, уважність, уміння генерувати ідеї, мовленнєву діяльність, ораторське мистецтво, толерантність до думок інших, коректність і тактовність, які дуже важливі 
для майбутніх викладачів 3ВО. Диспут дидактично доцільний до вивчення найбільш проблемних та суперечливих тем дисципліни (наприклад, в курсі «Педагогіка вищої школи», обговорюючи сучасний Закон України про вищу освіту, фахову передвищу освіту).

Практика свідчить, що найскладнішою формою проведення семінару $є$ семінар-конференція. Хоча проведення студентських конференцій є доволі розповсюдженою практикою вищої школи. Слід відмітити, що така форма семінарського заняття передбачає ретельний відбір теми, чітку постановку мети, декомпозицію завдань, і розподіл цих завдань серед магістрантів з урахуванням їхніх індивідуальних можливостей. Для магістрантів - це ретельна підготовка доповіді на конференцію, іiі презентація, відшліфовування умінь презентувати результати пошуково-дослідницької діяльності. Водночас, це уміння ставити запитання доповідачеві, а також уміння швидко реагувати й відповідати на запитання, якщо сам магістрант виступає у ролі доповідача.

Досить схожий за суттю - семінар-прес-конференщія. Він характеризується тим, що група магістрантів готують доповіді з передбачених планом семінарського заняття питань, а інші магістранти-слухачі ставлять доповідачам додаткові запитання.

У процесі вивчення дисциплін освітньої програми «Педагогіка вищої школи» вдалим буде використання проблемного семінару. Його метою є сприяння виробленню максимальної кількості ідей, покликаних вирішити певну проблему, запропоновану викладачем. Основними структурними елементами такого заняття є: створення проблемної ситуації; формулювання проблеми; висунення гіпотез; перевірка висунутих гіпотез; аналіз результатів перевірки гіпотез, висновок і узагальнення; повернення до проблемної ситуації (Фіцула, 2010). Магістрантові за кілька хвилин необхідно представити власний варіант розв'язання проблемної ситуації. Після колективного обговорення інший магістрант пропонує своє бачення проблеми. Так, кожен учасник семінару має право висловити власну думку та донести іiі оточуючим, а на основі колективного обговорення виокремлюються найбільш конструктивні ідеї. Проблемний семінар характеризується активною участю магістрантів в обговоренні та розв'язанні ключових проблем, на яких викладач прогне зосередити їхню увагу. Цінність проблемного семінару в тому, що самі знання магістранти отримують як побічний продукт, адже головна увага була зосереджена власне на шляхах розв'язання окресленої проблеми (Малафіїк, 2015; Чернилевский, 2020).

Семінар-аукціон, семінар-вікторина, семінар-змагання (турнір) - це ті форми організації навчання магістрантів, де можна оцінити рівень їх знань за допомогою ігрових технологій. Так, для проведення аукціону обирається експертна група, в якій ії керівник є ведучим. Саме він і визначатиме магістрантів, які називатимуть номер запитання, що буде «продаватися». «Покупець» (магістрант) має право придбати «товар» (відповісти на запитання) та заробити бали. Відповідь на пропоноване питання можна уточнювати чи деталізувати, отримавши при цьому додаткові бали. Купує товар той, хто дає останню відповідь (Чернилевский, 2020). Такий аукціон буде доречним у процесі вивчення кількох тем дисципліни «Планування і організація навчального процесу у вищій школі» (при цьому продавати можна методики, посібники, ідеї тощо). Навчальні заняття у формі вікторини найчастіше використовуються для узагальнення знань 3 вивченої теми. Самі запитання можуть звучати по-різному: «продовжити речення», «про кого йде мова», «чиї це слова», «кому належить історичний портрет» та ін. Таке семінарське заняття допомагає виявити ступінь оволодіння матеріалом на занятті 3 метою ліквідації «білих плям» у процесі подальшої навчально-пізнавальної діяльності магістрантів.

Безперечно, семінар повинен включити магістрантів у роботу, поглинути думки і почуття всіх його учасників, бути цікавим і захоплюючим. Цю мету реалізують семінарські заняття у формі змагання. Наприклад, конкурсні змагання можна провести різної спрямованості: «конкурс на кращого знавця історії педагогіки», «змагання любителів педагогічних кросвордів», «конкурс педагогів-майстрів», «змагання на кращий освітній проєкт», «конкурс методистів», «конкурс на знання закону про освіту». Схожим за своєю суттю є семінарське заняття у формі «турніру». Його учасниками є одна чи дві групи магістрантів. Вони наперед ознайомлені із питаннями, винесеними на такий семінар та змагаються між собою (група 3 групою, одна підгрупа з іншою). Крім підготовки аудиторії (розміщення столів, тематичне оформлення) слід звернути увагу на організацію роботи на занятті. Фронтальне опитування, розв'язування творчих завдань, карток, зачитування підготовлених повідомлень, обговорення та дискусії - все це може по черзі використовуватися у процесі подібного заняття. Переможець визначається за кількістю балів, що нараховуються за кожен турнір.

Нині особливо актуальним $є$ організація навчальної діяльності в режимі онлайн, відтак, семінар трансформовано у вебінар - інтерактивне віртуальне навчальне заняття, що проводиться викладачем дистанційно в мережі Інтернет, у процесі якого магістранти беруть активну участь в обговоренні проблемних питань та дискусії з використанням різноманітних програмних засобів та інтернет-ресурсів. Вебінари, особливо, на платформах дистанційного навчання з можливістю відеозв'язку, дозволяють демонструвати презентації, колективно переглядати сайти, відеофайли і зображення, спільно працювати з пропонованими документами і додатками, вести дискусії за допомогою відеозв'язку. Будь-яке заняття може бути записане і згодом використане для безлічі цілей: формування внутрішньої кафедральної бібліотеки знань, викладання в Інтернет у відкритий для всіх чи тільки для учасників доступ, створення цифрових наративів для удосконалення 
освітнього процесу тощо (Кононец, 2020). По суті, вебінар є віртуальним семінаром, який організований за допомогою Інтернет-технологій за наявності мікрофона та вебкамери у комп'ютерному девайсі. Він має головну ознаку семінару - інтерактивність, яка може бути забезпечена за допомогою моделі: «доповідач - слухачі», які ставлять питання та обговорюють їх, причому в ролі доповідача може бути як викладач так і магістрант, залежно від ролі, яку він має виконувати за сценарієм проведення такого віртуального семінару (Кононец, 2020; Kononets, Nestulya, 2020).

Висновки. Аналіз найпопулярніших видів семінарів дозволяє говорити про вирішальну роль творчого підходу викладача до процесу їх утілення. Такі креативні семінарські заняття з цікавістю сприймають саме магістранти освітньої програми «Педагогіка вищої школи», адже вони, як майбутні викладачі 3ВО, фахової передвищої освіти будуть упроваджувати такі ж організаційні форми навчання у майбутній професійній діяльності. Водночас, проведення таких семінарів сприятиме професійному зростанню магістрантів під час навчання у ЗВО. Підсумовуючи вище викладене, зазначимо, що інноваційні форми організації навчальної діяльності магістрантів забезпечують високу пізнавальну активність та інтерес до вивчення педагогічних дисциплін, удосконалюють уміння працювати з декількома джерелами, порівнювати виклад одних і тих же питань, виражати свою точку зору при колективному обговоренні загальних проблем, систематизувати й узагальнювати отримані знання.

\section{Список використаних джерел}

Гриньова, М. В., Кононец, Н. В., Дяченко-Богун, М. М., Рибалко, Л. М. (2019). Ресурсно-орієнтоване навчання студентів в умовах здоров'язбережувального освітнього середовища. Інформаційні технологї̈ $i$ засоби навчання, 72 (4), 182-193.

Кононец, Н. В. (2020). Дидактичний потенціал хмарної платформи Zoom Cloud Meetings для проведення вебінарів та відеолекцій. Вісник Польсько-украӥнської науково-дослідної лабораторії дидактики імені Я. А. Коменського. Вип. 2(21): Актуальні проблеми сучасної психодидактики: філософські, психологічні та педагогічні аспекти: матеріали 4 Міжнар. наук.-практ. конф. (рp. 60-63). Умань: Візаві.

Малафіїк, І. В. (2015). Дидактика новітньої школи. Київ: Слово.

Фіцула, М. М. (2010). Педагогіка вищзої иколи: навч. посіб. Київ: Академвидав.

Чернилевский, Д. В. (2020). Дидактические технологии в высшей школе: учеб. пособие для вузов. Москва: ЮНИТИ-ДАНА.

Kononets, N., Nestulya, S. (2020). The implementation experience of students mobile training in the fundamentals of leadership as a resource-oriented form. Інформаційні технологї і засоби навчання, 78, 4, 116-131.

\section{References}

Chernilevskii, D. V. (2020). Didakticheskie tekhnologii v vysshei shkole [Didactic technologies in higher education]: ucheb. posobie dlia vuzov. Moskva: IuNITI-DANA [in Russian].

Hrynova, M. V., Kononets, N. V., Diachenko-Bohun, M. M., \& Rybalko, L. M. (2019). Resursno-oriientovane navchannia studentiv v umovakh zdorov'iazberezhuvalnoho osvitnoho seredovyshcha [Resource-oriented learning of students in a healthy educational environment]. Informatsiini tekhnolohii $i$ zasoby navchannia [Information technologies and teaching aids], 72 (4), 182-193 [in Ukrainian].

Fitsula, M. M. (2010). Pedahohika vyshchoi shkoly [Pedagogy of high school]: navch. posib. Kyiv: Akademvydav [in Ukrainian].

Kononets, N. V. (2020). Dydaktychnyi potentsial khmarnoi platformy Zoom Cloud Meetings dlia provedennia vebinariv ta videolektsii [Didactic potential of the Zoom Cloud Meetings cloud platform for webinars and video lectures]. In Visnyk Polsko-ukrainskoi naukovo-doslidnoi laboratorii dydaktyky imeni Ya. A. Komenskoho. Vyp. 2 (21): Aktualni problemy suchasnoi psykhodydaktyky: filosofski, psykholohichni ta pedahohichni aspekty [Bulletin of the Polish-Ukrainian Research Laboratory of Comenius Didactics. Vip. 2 (21): Actual problems of modern psychodidactics: philosophical, psychological and pedagogical aspects]: materialy 4 Mizhnar. nauk.-prakt. konf. (pp. 60-63). Uman: Vizavi [in Ukrainian].

Kononets, N., \& Nestulya, S. (2020). The implementation experience of students mobile training in the fundamentals of leadership as a resource-oriented form. Informatsiini tekhnolohii $i$ zasoby navchannia [Information technologies and teaching aids], 78, 4, 116-131.

Malafiik, I. V. (2015). Dydaktyka novitnoi shkoly [Didactics of the newest school]. Kyiv: Slovo [in Ukrainian]. 
KONONETS N., NESTULA S.

University of Ukoopspilks "Poltava University of Economics and Trade", Poltava, Ukraine

\section{INNOVATIVE FORMS OF SEMINAR LESSONS IN THE PROCESS OF PROFESSIONAL GROWTH OF MASTERS OF THE EDUCATIONAL PROGRAM "PEDAGOGY OF HIGHER SCHOOL"}

The essence of innovative forms of organization of seminars in the process of professional growth of undergraduates of the educational program "Pedagogy of higher school" in the field of knowledge 01 Education / Pedagogy of specialty 011 Educational, pedagogical sciences is analyzed in the work. The following forms of innovative seminars that will promote the professional growth of undergraduates while studying in higher education are characterized: seminar-extended conversation, seminar-report (message), discussion of abstracts and creative works, annotated reading, seminar-problem solving, in the form of a TV program, seminar-debate (discussion), seminar-conference, seminar-press conference, problem seminar, seminarauction, seminar-quiz, seminar-competition (tournament), webinar.

Analysis of the most popular types of seminars allows us to talk about the crucial role of the teacher's creative approach to the process of their implementation. Such creative seminars are received with interest by masters of the educational program "Higher School Pedagogy", because they, as future teachers of free economic education, professional higher education will introduce the same organizational forms of learning in future professional activities. At the same time, holding such seminars will promote the professional growth of undergraduates while studying in the Free Economic Zone. Summarizing the above, we note that innovative forms of organizing the educational activities of undergraduates provide high cognitive activity and interest in the study of pedagogical disciplines, improve the ability to work with multiple sources, compare the same issues, express their views in collective discussion of common problems. and summarize the knowledge gained.

Key words: master's degree, higher school pedagogy, seminar, professionalization seminar, innovations

Стаття надійшла до редакції 07.04.2021 p. 